\title{
Edith Ehrman
}

\section{$1932-1974$}

On November 13, Edith Ehrman, Manager of the Foreign Area Materials Center, State University of New York, died after a long illness at the age of 42. She was the Manager of the Foreign Area Materials Center since its inception almost I years ago. Indeed, to many Edith was the Foreign Area Materials Center, and properly so. Her creative sense, her unusual ability to gauge the relevance of her ideas for others, above all her commitment to the intellectual quality of the end result have characterized the work of FAMC from the beginning.

The Foreign Area Materials Center provided the initial stimulus which led to the organization of the Council for Intercultural Studies and Programs, and so Edith was intimately involved in the activities and meetings and conferences of the Council. She shared the editorial burdens of its publication, ISIS, from the very first issue, infusing its pages with her gift for clarity of expression and with her sense of what would really be helpful to its readers.

She also served the Association for Asian Studies giving unstintingly of her editorial skills. Since 1964 she was Associate Editor of the Association's Newsletter in an earlier form, and when the Professional Review was established, she became Associate Editor of that publication, serving through the current issue.

She was Coordinator of the Association's Annual Meeting book displays for 15 years. Her thoroughness and managerial skills in this endeavor made the yearly exhibit a most effective showcase for publishers and one of the best of any professional association. In 1967 she arranged an outstanding international book exhibit when the XXVII International Congress of Orientalists met in Ann Arbor, Michigan for the first time in the United States since its founding in 1873.

But what mattered most to her was the "floating world" of Japanese art-ukiyo-e. A founder of the Japan House Gallery and a member of the Visiting Committee at the Freer Gallery, she was an active collector of Japanese prints, and her discriminating taste soon brought her international recognition. Here her affection and enthusiasm for living found its most meaningful expression, and it is only fitting that the Freer Gallery should now be exploring the creation of a memorial to Edith to give a proper opportunity to those who would wish to honor her memory.

In her last difficult months, she displayed extraordinary courage born of her love of life. These lines of Elizabeth Barrett Browning capture as well as words ever can Edith's spirit to the very end:

\section{Straightway I was 'ware,}

So weeping, how a mystic shape did move

Behind me, and drew me backward by the hair

and a voice said in mastery while I strove, ...

'Guess now who holds thee?'-'Death', I said, but there

The silver answer rang, ... 'Not Death, but Love.'

W ARD MOREHOUSE 